\title{
Combatting Insider Trading in Tanzania: The Adequacy of the Capital Markets and Securities Act of 1994 and the Companies Act of 2002
}

\author{
Hanifa T. Massawe / Mwajuma Kadilu*
}

\begin{abstract}
Sub-Saharan African countries have been continually searching for opportunities to transform their economic fortune. Among the central components for the envisioned transformation is the development of viable securities markets. These countries envision that the increasing demand for domestic and foreign capital can be satisfied by robust securities markets in terms of operation and control of insider trading practices. However, this objective may not be attained where the securities business is fouled with insider trading practices without adequate legal regime to counter such practices. In this era where the Tanzanian capital market is exposed to international investment and the need to boost its economy, regulation of such market in terms of insider trading practices is of utmost importance. This article is aimed at analysing the adequacy of the Capital Markets and Securities Act of 1994 and its regulations in combating insider trading practices for companies listed in the Dar es Salaam Stock Exchange. From the discussion in this article, it is clear that the legal framework on insider trading in Tanzania is characterized by gaps, duplications, and ambiguities. At the end of the article it is concluded that, such legal regime is not adequate in combating insider trading practices in the stock market in Tanzania, thus amendment of the law is considered necessary. This work intends to shed light on insider trading and the importance of regulation for such offence.
\end{abstract}

\section{Introduction}

\subsection{The Concept of Insider Trading}

Insider trading refers to the practice of "insiders" trading on shares of a company for which they have privileged material information not available to the "public", and for which they

* Hanifa T. Massawe (LL.B) Mzumbe University (Tanzania), LLM (Mercantile Law) Stellenbosch University (Cape Town, South Africa); Lecturer at Mzumbe University, Faculty of Law (Department of Economic Law), Morogoro, Tanzania, Advocate of the High Court and Subordinate Courts thereto, Contacts: Postal Address: P.O. Box 9, Mzumbe University, Morogoro, Tanzania, E-mail: massawehanifa@yahoo.com; Mwajuma Kadilu (LL.B) University of Dar es Salaam (Tanzania), LLM (University of Dar es Salaam), Assistant Lecturer at Mzumbe University, Faculty of Law (Department of Economic Law), Morogoro, Tanzania, Advocate of the High Court and Subordinate Courts thereto, Contacts: Postal Address: P.O. Box 9, Mzumbe University, Morogoro, Tanzania, Email:mkadilu@yahoo.com. 
seek to gain pecuniary or other benefits. ${ }^{1}$ The term is also frequently used to refer to a practice in which an insider or a related party trades basing on material non-public information obtained during the performance of his duties at the company, or in breach of a fiduciary duty. $^{2}$

In most cases such a practice is conducted fraudulently, where the person who has obtained the information has a fiduciary duty to share it but fails to exercise it. ${ }^{3}$ A number of scenarios may illustrate the manifestation of this wrong, for instance; where one who has access to first hand information about potential mergers, buys shares in a company before the news of the merger becomes public. This would result to the increase of the share price of the company in question after the insider sells the shares and thus makes a quick profit. Another scenario is where a director sells shares in his or her company before negative news about the company reach the public domain, leading to the decline of the share price. ${ }^{4}$

The term "insider" on the other hand refers to any person or group that is able to gain such privileged information about a company. Insiders can include directors, managers or other employees of a company ${ }^{5}$ or (third) persons who gain privileged information indirectly from such managers or directors in a more intimate capacity as friends, family members or close but external business associates. ${ }^{6}$

\subsection{Impact of Insider Trading}

Since stock markets play a very important role in economic development all over the world, interest in the regulation or prohibition of insider trading and enforcement is inevitable. Insider trading practices undermine the integrity of the investing system and therefore discourage non-insiders from investing unless they believe they are operating in the same footing as insiders who are investing. Therefore, allowing insider trading to go unchecked would reduce a number of investors willing to invest their capital and therefore could potentially harm the economy as a whole.

Insider trading has the potential to manipulate stock prices to the harm of the investing public and to make insiders gain considerable profits based on unfair access to information

1 O'Hara, A. (2001), Insider Trading in Financial Markets: Legality, Ethics, Efficiency, in: International Journal of Social Economics, vol. 28, pp. 1046-1063.

2 Harris, L. (2003), Trading and Exchanges, Oxford Press, Oxford, p. 586.

3 Shaw, W. and Barry V. (2012), Moral Issues in Business, $12^{\text {th }}$ edition, Wadsworth, Belmont, pp. 586-587.

4 Ibid.

5 Machan, T. (1996), What is Morally Right with Insider Trading, Public Affairs Quarterly, vol. 10, pp. 135-137.

6 Like those persons who have a contractual or supply linkage to the company as well as those who print annual reports or stockbrokers who may inadvertently gain an information advantage. 
about the company. ${ }^{7}$ Moreover, it is harmful from the market point of view as the investor confidence is eroded rendering more difficulty in raising capital and thus leading to inefficiency of the market.

Generally, insider trading is considered unfair, especially to small shareholders, as it destroys the "level playing field" for all investors who approach the market to transact in securities. Harm is caused whether it is to an individual or the company, or to the market. Individuals might not realise that they are victims, but they nevertheless suffer at the hands of an insider trader. They either sell shares for less than their true value or purchase shares that are about to lose value, meaning they are taken advantage of, or deceived.

\subsection{Adequacy of the Legal Regime on Insider Trading}

Although Tanzania has put in place a legal regime to deal with insider trading, still the law on the subject remains largely inadequate. To justify this contention, this article examines the regulation of insider trading for listed companies in Tanzania in line with the Capital Markets and Securities $\mathrm{Act}^{8}$, hereafter referred to as CMSA, its regulations and the Companies Act $^{9}$ by analysing the strength of the provisions therein in combating insider trading practises in the Dar es Salaam stock market.

To establish the adequacy of the two legal instruments above in combating insider trading practises, the authors aim at carefully scrutinising the couching of the provisions of these laws to find out whether they successfully serve the need of their enactment. They will also consider the lessons of the Securities Exchange Act of 1934 as it represents an advanced version of an insider trading legislation. It should be borne in mind that the authors did not conduct any field research in as far as this article is concerned only about a library research to that effect.

\section{The Historical Background of Insider Trading Laws}

Adequate insider trading laws are extremely important to the operation of the securities markets. As these laws rest on legal concepts of breach of fiduciary duty and misappropriation, they serve to improve confidence and integrity of the securities markets. The investing public has a legitimate expectation that the prices of actively traded securities reflect publicly available information about the financial condition of the securities. The United States of America are considered the birth place of the modern day insider trading legislation following the effects of the Great Depression of the 1920's where struggles to boost economic

7 Estrada, J. (1994), Insider Trading: Regulation, Deregulation and Taxation, in: Swiss Review of Business Law, vol 5, pp. 346-348.

8 Act No 5 of 1994.

9 Cap 12 R.E of 2002. 
growth were a major concern. ${ }^{10}$ In an effort to combat insider trading in the stock markets, the Securities Exchange Commission, hereafter referred to as SEC, was established by the United States Congress under the Securities Exchange Act of 1934, hereafter referred to as SEA. ${ }^{11}$ The main reason for the creation of the SEC was to regulate the stock market and prevent corporate abuses relating to the offering and sale of securities and corporate reporting. ${ }^{12}$

Currently, the SEC is responsible for administering seven major laws that govern the securities industry. These laws are the Securities Act of 1933, the Securities Exchange Act of 1934, the Trust Indenture Act of 1939, the Investment Company Act of 1940, the Investment Advisers Act of 1940, the Sarbanes-Oxley Act of 2002 and most recently, the Credit Rating Agency Reform Act of 2006.

In Tanzania, globalization has resulted in the opening of markets and injection of direct foreign investment in markets of emerging economies. The foregoing has witnessed market reforms whereas the governments' investments in business have been on the decline while private capital has assumed a centre role. ${ }^{13}$

Injection of private capital in direct foreign investment has been made through the corporate vehicle where some businesses in Tanzania are conducted through public listed companies with wide spread shareholders, both local and foreign. Given the low level of the economy in the country and poor knowledge of the advantages of investing in the capital market by corporate entities, an attribution is made to the small number of companies listed in the one and only Dar es Salaam Stock Exchange.

\section{Insider Trading Practices under the Securities Exchange Act of 1934}

The Securities Exchange Act (SEA) makes unlawful the use, "in connection with the purchase or sale of any security of any manipulative or deceptive device or contrivance in contravention of such rules and regulations as the Commission may prescribe". ${ }^{14}$ Insider trading prohibitions in the United States of America began in the case of SEC v. Texas Gulf Sulphur $\mathrm{Co}^{15}$ where TGS, as it is commonly known, rested on a policy of equality of access to information. Accordingly, under TGS virtually anyone who possessed material non-pub-

10 Macey, J. R./D. Haddock (1987), A Coasian Model of Insider Trading, Faculty Scholarship Series, Paper 1774, p. 321.

11 Ibid.

12 Bergmans, B. (1991), Inside Information and Securities Trading: A Legal and Economic Analysis of the Foundations of Liability in the USA and the European Community. $1^{\text {st }}$ edition, Springer, $p$. 120.

13 Bagachwa M.S.D, et al. (1992), Market Reforms and Parastatal Restructuring in Tanzania, Dar es Salaam: Economics Research Bureau, p. 23.

14 Section 10(b) of the Securities Exchange Act of 1934.

15401 F. 2 d 833 ( 2 d Cir. 1968). Prior to TGS, the federal prohibition was effectively limited to faceto-face and control transactions. 
lic information was required either to disclose it to the investing public before trading or to abstain from trading in the affected company's securities. If there would be trader's fiduciary duties precluding him from disclosing the information prior to trading, abstention was the only option.

To date, the Supreme Court of the United States of America has embraced two complementary theories of insider trading interpreting section 10(b) and its implementing rules. The first theory was recognized in the case of Chiarella $v$. United States ${ }^{16}$ and known as the classical theory which provides that corporate insiders are forbidden to trade on confidential information in violation of a fiduciary duty to their company's shareholders. The Chiarella Court emphasized that a central indication of corporate insider status is whether the actor is under a fiduciary duty to the shareholders of his or her company. The Second Circuit, which was the court below, had adopted a broad definition of duty, assigning a fiduciary duty to "anyone," not merely insiders, receiving material nonpublic information; the Supreme Court explicitly rejected that definition. Three years later, in Dirks v. Securities Exchange Commission ${ }^{17}$ the Court reaffirmed that interpretation and reiterated that a predicate of insider trading liability is the existence of a fiduciary relationship.

The second theory of insider trading, known as the misappropriation theory, was recognized by the Supreme Court in United States v. O'Hagan. ${ }^{18}$ The theory extended insider trading liability to corporate outsiders who misappropriate, and then trade on, confidential information in violation of a duty of trust or confidence owed to them. The theory reiterates that the corporate outsiders are to be found liable under section 10(b). In O'Hagan the Court held that, a law-firm partner who is aware of a regulated client's private plans to acquire stock in another company should not trade on that information. These two theories of insider-trading liability share the common requirement of breach of a fiduciary under section $10(\mathrm{~b})$ of the SEA.

In enforcing this law, the SEC has been authorised to bring civil enforcement actions against individuals or companies alleged to have committed accounting fraud, provided false information, or engaged in insider trading or other violations of the securities law. ${ }^{19}$ The SEC also works with criminal law enforcement agencies to prosecute individuals and companies alike for offences which include criminal violation of the securities laws.

16445 U.S. $222(1980)$.

17463 U.S. 646 (1983).

18521 U.S. 642, 655 (1997).

19 Meyer, C. (1987), The Securities Exchange Act of 1934 Analysed and Explained, Emory Fitch Inc. Printers, New York, p. 25; consider also the case of SEC v Martha Stewart \& Peter Bacanovic where it was alleged that Stewart committed illegal insider trading when she sold stock in a biopharmaceutical company, ImClone Systems, Inc., on Dec. 27, 2001, after having received an unlawful tip from Bacanovic, at the time a broker with Merrill Lynch, Pierce, Fenner \& Smith Incorporated. Sam Waksal the director of ImClone was sentenced to seven years in prison, $B a$ canovic sentenced to five months in prison and fined while Martha was sentenced to five months in prison and USD five million fine. 
In an attempt to establish an equal level-playing field for all investors, the SEC maintains an online database called EDGAR (the Electronic Data Gathering, Analysis, and Retrieval system) from which investors can access information filed with the agency. ${ }^{20}$ The system also collects complaints from investors to help the SEC to track down violators of the securities laws and publications on investment-related topics for public education. ${ }^{21}$ The Securities Exchange Act also governs the disclosure in materials used to solicit shareholders' votes in annual or special meetings held for the election of directors and the approval of other corporate action. The information, contained in proxy materials, must be filed with the Commission in advance of any solicitation to ensure compliance with the disclosure rules.

The legislation of the United States of America has led the way in relation to insider trading regulation practices in different countries but legislations have only slowly been introduced in other nations. The United Kingdom ${ }^{22}$ and Japan ${ }^{23}$ have generally followed the example of the United States of America in the 1970s-1990s. The European Community oversees such legislation in its member nations, although much of the legislation passed has not been adequately policed. Australia has legislation similar to the USA, and more recently legislation on insider trading have been under way in parts of Asia. ${ }^{24}$ In African countries, insider trading legislation has been an influence of globalization leading to a formulation of insider trading laws which reflect on their economic, social and political experiences.

\section{The Regulation of Insider Trading in Tanzania}

Trade in securities is an area which is fairly new in Tanzania that comes about as a result of the adoption of the market oriented economy. ${ }^{25}$ An observation can be made that the pace of growth of the securities business in the country is still very low warranted by the existence of only one capital market since 1994, namely, the Dar es Salaam Stock Exchange as compared to the United States where the securities business is highly developed evidenced by a large number of stock markets. The Dar es Salaam Stock Exchange, hereafter referred to as the DSE, was established in 1996 and became operational in 1998. Currently the DSE has 17 listed companies. ${ }^{26}$

$20 \mathrm{http}: / /$ www.sec.gov/investor/pubs/insidertradingguide.html (retrieved in October 2012).

21 www.sec.gov/edgar.shtml (retrieved in October 2014).

22 The Financial Services and Markets Act of 2000.

23 The Japan Securities Exchange Law of 1988.

24 The Corporations Act of 2001.

25 Economic reforms which were implemented in Tanzania from the mid-1980s entailed the shift from an

administratively managed and public sector led economy to a market oriented and private sector led economy.

26 At 2012 the market has 11 listed domestic companies and six cross listed firms. 
To ensure proper regulation of the listed companies' activities in as far as dealing in securities is concerned the Capital Markets and Securities Act $^{27}$ hereafter referred to as the Act and its respective Regulations ${ }^{28}$ were enacted establishing the Capital Markets Authority as a body responsible for the enforcement of the same. ${ }^{29}$ The Act was amended in the year 1997 to incorporate changes which were related to market players and operators for the purpose of giving more protection and security to the securities investors. In addition to these main laws there are other laws which have a direct impact on the operation of capital markets such as the Companies Act $^{30}$ and the Fair Competition Act. ${ }^{31}$

The Act establishes the Capital Markets and Securities Authority, hereafter referred to as the Authority, which is a body corporate with perpetual succession and having a common seal. ${ }^{32}$ It is the principal administrative body in the institutional infrastructure of Tanzania's securities markets which provides a regulatory framework aimed at nurturing innovation, promotes flexibility and self regulation in order to maintain investor confidence and to safeguard the market against insider trading practices. In controlling these malpractices, the Authority just like its American counterpart, the Securities Exchange Commission, is responsible to maintain surveillance over securities, to ensure orderly and equitable dealings in securities; ${ }^{33}$ and to register, licence, authorize or regulate stock exchanges. ${ }^{34}$

The CMSA specifically provides for issues pertaining to securities business under Part IX of the Act. ${ }^{35}$ Insider trading as an offence in Tanzania is established under section 112 of the same Act imported by the words "prohibition of dealings in securities by insiders". The section requires that a person who is, or has at any time in the preceding six months, prior to a specific deal been connected with a body corporate shall not deal in any securities of that body corporate if by reason of his association, he is in possession of information that

27 Act No 5 of 1994.

28 The Capital Markets and Securities (Foreign Companies Public Offers Eligibility and Cross Listing Requirements) Regulations, 2003, Capital Markets and Securities (Foreign Companies Public Offers Eligibility and Cross Listing Requirements) Regulations, 2003 [amended in 2005], Capital Markets and Securities (Foreign Investors) Regulations, 2003 Capital Markets and Securities (The Capitalization and Rights Issue) Regulations, 2000, Capital Markets and Securities (Advertisements) Regulations, 1997, Capital Markets and Securities (Accounting and Financial Requirements) Regulations, 1997, Capital Markets and Securities (Prospectus Requirements) Regulations, 1997, Capital Markets and Securities (Licensing) Regulations, 1996, Capital Markets and Securities (Establishment of Stock Exchange) Regulations, 1996, Capital Markets and Securities (Registers of Interests in Securities) Regulations, 1996 Capital Markets and Securities Authority Enforcement Guidelines, 2004, Capital Markets and Securities (Corporate Governance) Guidelines, 2002, and the Capital Markets and Securities (Custodian Securities) Regulations, 2006.

2930 See fn. 28.

30 Cap 12 R.E.2002.

31 Act No 8 of 2003.

32 Under section 6(2) CMSA.

33 Section 10 of the CMSA.

34 Section 10 (c) of the CMSA.

35 Section 106-118 of the CMSA. 
is not generally available but, if it were, might materially affect the price of those securities. The Act further precludes anyone who has at any time in the preceding six months prior to a specified deal been connected with a body corporate from dealing in securities of another body corporate if by reason of his connection with the first-mentioned body corporate he is in possession of information that is not generally available and that if it were, it would likely affect materially the price of those securities. ${ }^{36}$

From the presentation of section 112 of the Act, one can observe that the Act carries a prohibition of insider trading from the point of view of inherited English case laws which reflects on insider trading from the perspective of the fiduciary duties of directors. ${ }^{37}$ However the Tanzania law on the subject remains largely inadequate. The position of directors as fiduciaries has been discussed in the famous case of Guinness Plc v Saunders ${ }^{38}$ where Lord Goff advocated that directors must not put themselves in a position where there is a conflict between their personal interests and their duties as fiduciaries. The Saunders case is a strong affirmation by the House of Lords of the importance of the rule of equity which prohibits a fiduciary from placing himself in a position of conflict except as expressly authorised by the articles. ${ }^{39}$ This standpoint is particularly important in the company context where directors are frequently faced with conflicts which can produce significant personal gain.

Although Tanzania has had enough to learn from the United States' misappropriation theory and classical theory, it is still observed that the provisions on insider trading as presented in the Act have not been put to test through case laws. Due to this fact that the authors have not come across any reported or unreported insider trading case laws in Tanzania to date. However that does not mean that there are no insider trading practices taking place in the country but seems rather to be a result of non-awareness issues on the offence or the way the wording of the statute has been improperly couched to clearly present the offence.

Apart from the Capital Markets and Securities Act, the Companies Act ${ }^{40}$ being the regulator of companies in Tanzania does not expressly establish the offence of insider trading. Given this situation one could speculate that maybe the lawmaker purposely left the instrument ajar so that reliance may be placed on proper construction of the duties of directors as promulgated in section 209 of the Companies Act to bring in the offence of insider trading. Section 209 stipulates in mandatory terms on the disclosure requirements by directors of their interests in contracts. The disclosure requirement in this context may be stretched to cover disclosure of information possessed by a director on the securities for the purpose of avoiding insider trading by the director as a fiduciary. It is also observed that the Penal

36 Section 112(2) (a) and (b) of the CMSA.

37 Walsham v Stainton (1863) 1 De Gex, Jones \& Smith 678; Percival v Wright (1902) 2 Ch. 421.

38 [1990] 2 AC 663.

39 Farrar, J./B. Hannigan (1998), Farrar's Company Law, Fourth Edition, Butterworths, Dublin, p. 401.

40 Cap 12 R.E 2002. 
Code $^{41}$ being the law which regulates crimes in the country does not provide for the offence of insider trading.

\section{Weaknesses of the Capital Markets and the Securities Act and the Companies Act in Combatting Insider Trading in Tanzania}

Much as the legislature has made efforts to enact the Capital Market and Securities Act, it is the conviction of the authors that some provisions of this law need to be amended to successfully combat insider trading practices like its American counterpart.

The Tanzanian CMSA has not been couched to make a clear definition of the term "insider", instead section 5 of the same Act makes reference to "person deemed to have interest in securities". Such presentation is considered general and ambiguous and fails to paint a clear picture of who an insider is, leaving wide room for speculation and rendering it difficult to categorize who is and who is not liable as an insider in order to establish an effective and measured legislative prohibition on insider trading. Again insider trading being an offence has not been accorded a proper definition in the Penal Code ${ }^{42}$ and the same goes for the Companies Act. ${ }^{43}$

Another weakness is observed in the fact that the CMSA does not properly define insider trading in clear terms, instead, the same has been given the name "dealing in securities". ${ }^{44}$ Despite the fact that the wording may be too general still the definition is too wide and ambiguous to specifically reflect on insider trading as an offence. Thus, if the same law is prohibiting dealings in securities by insiders ${ }^{45}$ and there is no clear definition of the wrongful act, then such is considered as an anomaly.

Furthermore, it has not been made clear in the instrument as to what refers "non-public material information" which if divulged would amount to insider trading whether it be at the company level or in the stock market. Such clarity is of vital importance since a clear demarcation has to be made between information that has a direct effect on the market value of securities and information merely arrived at as a result of perceptive analysis of generally known facts by the prospective investors. A clear meaning on the quality information likely to amount to insider trading is necessary from the point of view of prospective traders, and thus the law should be properly understood to inform on when the information gathered amounts to 'inside information,' or from a regulatory point of view what type of information should be viewed as inside information. This implies that all persons that have such information are eliminated from taking part in trading in the shares to which the infor-

41 Cap 16 R.E 2002.

42 Cap 16 R.E. 2002.

43 Cap 12 R.E 2002.

44 Section 2 of the CMSA.

45 As per section 112 of the CMSA. 
mation relates. In the context explained above, a clear understanding of the term inside information is of utmost importance.

To facilitate the discharge of its statutory mandate, the Authority has overwhelming powers $^{46}$ as amended by the Capital Markets and Securities (Amendment) Act of $2010^{47}$ to include duties, powers and a big responsibility of conducting investigations in many areas pertaining to securities business. ${ }^{48}$ This amorphous provision constitutes the Authority to be both judge and jury in determining what acts are incidental or conducive to the attainment of its objects. Similarly, the Authority enjoys extensive legislative powers in relation to the securities markets generally and its licensees, approved persons and listed companies in particular. It is empowered to inquire into the affairs of persons through an officer appointed by the chief executive officer, intervene in the management of a licensee, impose financial penalties for violations of the provisions of the Act, regulations, rules or procedures of any securities exchange by licensees, approved persons, listed companies or their directors or employees. Instead, the duty of the authority should only be on controlling insider trading practices rather than being overwhelmed by many activities which may in one way or the other render it inefficient in terms of regulating insider trading practices.

Analogous to the Authority, the Minister of Finance is also empowered to give to the Authority directions of a general or specific character as to the exercise of its functions and it shall be the duty of the Authority to give effect to any such directions. ${ }^{49}$ This provision duplicates the powers of the Capital Markets Authority and undermines its independence. It can be argued that the administrative structures in developed jurisdictions like the Securities Exchange Commission of the United States have evolved over time and are predicated on developed regulatory capacity with sufficient numbers of professionals and other supportive institutions. ${ }^{50}$ Such institutional mix is largely non-existent in developing jurisdictions. Replicating such administrative structures in Tanzania does not guarantee the development of deep and vibrant securities markets capable of successfully combating insider trading practices if given a higher degree of autonomy.

\section{Reform Strategies}

As observed in the discussion above, it is the proposition of the authors that the Companies Act should be amended to include provisions on insider trading in express terms. Although the fact that the lawmaker wisely decided to have a separate piece of legislation to handle insider trading practices for companies listed in the Dar es Salaam Stock Exchange seems a

46 Section 10 of the CMSA.

47 Section 3 Act No 10 of 2010.

48 Section 10 (1) (a)-(d), section 10(2) (a)-(w) of the CMSA.

49 Section 147 of the CMSA.

50 Philip, N. (1986), Securities Regulation in Malaysia: Emerging Norms of Government Regulation, in: Journal of Comparative Business and Capital Market Law, pp. 39-73. 
proper first step, then such law should furthermore be as clear as possible to pin down the wrongdoer to the liability in question. Thus it is proposed that the CMSA be amended to define in clear terms the word "insider" and "insider trading" so as to adequately serve the need of its enactment.

To ensure total eradication of insider trading, it is necessary for the authority to streamline its enforcement philosophy as it is currently too erratic and intermittent leading to uncertainty in the securities markets. The Authority should endeavour to develop an enforcement philosophy consistent with market needs. A clearly defined and implemented enforcement philosophy would instil certainty which in turn would promote investor confidence. It is advised that the authority should enlist the support of market intermediaries ${ }^{51}$ in its effort to nurture a culture of compliance to the CMSA. Thus a cordial working relationship between the Authority and market intermediaries would enhance certainty.

To promote investor awareness, the Act has been amended by the Capital Markets and Securities (Amendments) of 2010 to include investor education which plays a double role of enhancing investor protection and developing the securities markets. However the law is self limiting in the sense that the education is only for investors who are likely to engage in insider trading practices, while the same could be extended to the shareholders likely to be affected by the negative effects of insider trading committed by its companies. Also more education could be provided to the general public who is in one way or the other the whistle blower when it comes to the insider trading practices. Again the Act fails to prescribe the modus operandi for the same.

Apart from the legal mechanisms of prohibiting insider trading practices in Tanzania, companies may design control measures to prevent or monitor the misuse of confidential information by the insiders. This pertains to the formulation of policies and trainings relating to the treatment of confidential information by the company staff. The company may put in place strong ethical compliance policies in order to reduce the risk of breach of the insider trading laws.

Moreover, active steps should be taken to prevent unauthorized access to sensitive information through physical controls such as the use of ethical walls, which would include steps such as data encryption, password protocols, separate floors/ locked offices and secure network drives available only to employees.

Finally, because of the centrality of the Authority in the enhancement of securities markets, it is submitted that the Capital Markets Authority should be accorded sufficient independence to facilitate the effective execution of its mandate. It is desirable to shield the Authority from political interference by the executive arm of government in order to be capable to perform its activities impartially.

51 Market intermediaries has been defined in the Capital Markets and Securities (Amendments) Act 2010 to mean an individual or corporate body whose activities are provided for under this Act including but not limited to dealers, dealers' representatives, investment advisors, investment advisors' representatives, nominated advisors, nominated advisors' representatives, stock exchanges, collective investment schemes, securities depositories and custodian of securities. 


\section{Conclusion}

The analysis above shows that the legal and institutional framework on securities markets in Tanzania is for the most part statutory, as discussed in the relevant foreign legislations. However, the framework is characterized by gaps and duplications when it comes to combating insider trading practices, which can be remedied by amendments. An observation has also been made that, since the Tanzanian companies law has not played an instrumental role in combating insider trading, thus an argument can be made that it should be replaced with a more dynamic framework. It is particularly inadequate in relation to investor protection from insider trading point of view thus there seems an urgent need to align it with the securities markets legislation. 